\title{
Towards an indigenous model of conflict resolution: Reinventing women's roles as traditional peace- builders in neo-colonial Africa
}

\section{Christopher Isike and Ufo Okeke Uzodike ${ }^{\star}$}

\begin{abstract}
Women have always been at the centre of peace processes across different pre-colonial African societies. Their peace agency in these societies can be located in their cultural and socio-political roles as well as their contributions to the overall well-being of these societies. It is noteworthy that women's peacebuilding roles then were reinforced by perceptions which stereotyped women as natural peacemakers, and as being more pacific than men. However, women in neo-colonial African states appear to have lost this myth/sacredness that surrounded their being and social existence in pre-colonial Africa. This is because apart from being marginalised socially, economically and politically, they have increasingly become victims of male violence.

How and why did women transform from being active participants in precolonial politics and peace processes to being passive observers of politics and peacebuilding in neo-colonial Africa? And second, given their pre-colonial peacebuilding antecedents, do women have the potential to transform politics and conflict in neo-colonial Africa?
\end{abstract}

* Dr Christopher Isike researches and teaches African politics at the University of Zululand, South Africa.

Prof Ufo Okeke Uzodike is Head, School of Politics, University of KwaZulu-Natal, South Africa. He is also the editor of Afrikka: Journal of Politics, Economics and Society. 


\section{Reinventing women's roles as traditional peacebuilders in neo-colonial Africa}

In building towards an indigenous model of conflict resolution and peacebuilding, this paper contends that the feminist ethic of care (defined by ubuntu) that was appropriated by pre-colonial African women to wage peace and maintain societal harmony, is still very much a part of the core of contemporary African women, and can be appropriated in resolving subnational conflicts in neo-colonial Africa. Indeed, it is possible to develop it into a model of African feminist peacebuilding which can be utilised as an ideological rallying point to transform politics and create a suitable environment for development in the continent.

\section{Introduction}

Traditionally, women have always been at the centre of peace processes - from peacemaking to peacebuilding and even sometimes, preventive diplomacy across different pre-colonial African societies (Amadiume 1997; NgongoMbede 2003; Mohammed 2003). Women's peace agency in these societies can be located in their cultural and socio-political roles as well as their contributions to the overall well-being of these societies wherein these roles were reinforced by perceptions which stereotyped women as natural peacemakers, and as being more pacific than men.1 ${ }^{1}$ Oftentimes, women were symbolised as paragons of morality, sacredness, goodness and tenderness. Indeed, women's existence and power in pre-colonial African societies were based on an ethic of care that was rooted in their motherhood and their nature, which was tolerant of difference, collaborative, non-violent and, as such, peaceful (see Mazurana and McKay 1999).

However, women in neo-colonial African states appear to have lost the myth/ sacredness that surrounded their being and social existence in pre-colonial

1 Such perceptions were found even where women were known to be actively engaged in pre-colonial wars of conquest, initial resistance against colonial rule and the nationalist liberation struggles of the continent. For example, according to Becker (2003:55-56) 'it would be erroneous to assume that women and girls played no role in the encouragement of belligerent attitudes. Nor are there any indications that mothers would have raised their children in a way that would have discouraged their inclination to battle'. However, as Nodding explained, 'women's acceptance of war does not seem to emerge from seeing striving as a virtue but rather from a desire to remain in positive relation with those who worship striving' (Nodding in Van Soest 1995:168). 


\section{Christopher Isike and Ufo Okeke Uzodike}

Africa. This is because apart from being marginalised socially, economically and politically (Amadiume 1997; Nzeogwu 2000; Rehn and Johnson Sirleaf 2002), they have become victims of assorted forms of physical abuse and sexual violence based on a warped understanding of African patriarchies, ${ }^{2}$ which has produced negative masculinities in the continent (Isike and Okeke-Uzodike 2008). The negative impact of armed conflict and poverty on women is particularly unacceptable because not only are women disproportionate victims, they are in most cases excluded from peace processes and post-conflict reconstruction in their communities. ${ }^{3}$ Africa arguably presents a major challenge and fertile ground for conflict and peace studies because it has been more plagued by violent intraand inter-state conflict of various kinds since the 1960s than any other continent (Patel 2001:357).

While a multiplicity of factors is responsible for these conflicts, they all reflect the failure of national political systems to prevent them $a b$ initio, effectively manage their symptoms or mediate them when they occur. It is pertinent to note that the vast majority of world leaders, of governments and officials at all levels, and of the presidents and boardrooms of transnational corporations are men (Brine 1999:16). It is therefore not far-fetched to make two assumptions: first, that global power is gendered in favour of men, and second, based on this, that armed conflict has a masculine character in terms of causes since men dominate the decision-making structures and mechanisms that produce them in the first place. The question then is how and why did women transform from being active participants in pre-colonial politics and peace processes to being passive observers of politics and peacebuilding in neo-colonial Africa? How do they fare in these conflicts? And given their pre-colonial peacebuilding antecedents, do they have the potential to transform politics and conflict in neo-colonial Africa?

2 Masculinities are fluid and dynamic, and we cannot speak of a single universal African patriarchy. Over the time, different forms of patriarchies existed in different pre-colonial African societies.

3 Also, in moving beyond pacifist and thus essentialist perspectives of women, it should be noted that women's victimhood in conflict extends beyond the feminisation of violence to the feminisation of exploitation. Therefore while it is true that women do play active roles in conflict, we must also ask how they are recruited and drawn into conflict in the first place. 


\section{Reinventing women's roles as traditional peacebuilders in neo-colonial Africa}

This paper argues that the positive human factor values which defined womanhood in pre-colonial Africa have been corrupted over time by the colonial interruption of Africa's socio-cultural existence leading to the marginalisation, tokenisation and de-feminisation of women in political and peace processes in post-colonial Africa. Excluding women from these processes is an inherent weakness of extant statist and institutional approaches to understanding and resolving conflict in the continent as they undermine the human factor and human security basis of these conflicts. Also, even where women have been mainstreamed into politics in significant numbers, as in Rwanda, South Africa, Tanzania and Uganda, de-feminisation arising from the colonial corruption of gender relations makes their participation and representation in the public domain ineffective. Impliedly, the intervening socio-cultural variables that impede women's political participation and make their representation ineffective must be tackled to curb the incidence of armed conflict in Africa. One way to do this is to develop an African feminist paradigm of peacebuilding that can be appropriated as a practical conflict prevention and resolution model in the continent.

In building towards an indigenous theory of conflict resolution and peacebuilding, this paper therefore contends that the feminist ethic of care (defined by ubuntu) that was appropriated by pre-colonial African women to wage peace and maintain societal harmony, is still very much a part of the core of contemporary African women, and can be appropriated in resolving sub-national conflicts in neocolonial Africa. Indeed, this can be developed into a model of African feminist peacebuilding which can be utilised as an ideological rallying point to transform politics and create an environment conducive for development to take place. This conclusion is aptly supported by empirical findings from a previous study of women, politics and peacebuilding in the Niger Delta in Nigeria and KwaZuluNatal in South Africa (Isike 2009). However, it is noted that this paper is not in the first instance based on field work, but rather on a study of relevant literature and examples. Therefore, the use of empirical evidence from the above study is merely added as a clinching endorsement. 


\section{Conceptual framework of analysis}

This paper utilises a number of key concepts which are anchored on a larger human agency/ubuntu framework. These include conflict and peace. A starting point of understanding conflict as used in this paper is that it is an inevitable phenomenon in any society. In other words, it is an inherent dimension of human relations, an undercurrent of social relations. It arises out of, and shapes the challenge of how to manage economic, cultural, political and social relations. Underlying this challenge is the problem of scarcity, which necessitates competition, and requires cooperation to resolve. According to the Centre for Advanced Social Science (CASS) (2005), although conflict structures social relations by creating intersecting channels for societal (individual/collective/group) competition and cooperation, it also has to be understood in the context of disagreement over the values/ideals to inform the socio-economic and political organisation of state and society (CASS 2005:6-7). These include the social relations of production and the superstructure of culture, law and political relations, forms and systems of governance, structures and processes, including institutional ones, the distribution of and allocation of scarce resources and the direction and emphasis of public policies (CASS 2005:7). Viewed this way, there are different forms of conflict such as social conflict defined by economic scarcity that manifests in poverty (human insecurity) which impairs human existence. There is also armed conflict defined by socio-political differences over territory and mineral resources which manifests in political assassinations, violent confrontations and low-intensity warfare. Another form of conflict which this paper concerns itself with is inter-gender conflict, which is manifested in male violence against women. All these forms of conflict are rooted in the breakdown of social relations between individuals (i.e. men and women) and groups in societies; between communities over boundary lines and chieftaincy, and between states over territories and sovereignty. Concisely, conflict is inevitable and is rooted in relationships (see Lederach 2005; CASS 2005; Amisi 2008).

In the same vein, this paper conceptualises and utilises a relational notion of peace, not as the absence of violence, but as the presence of gender justice, mutual respect, tolerance and inclusion - the outcome of constructive transformation 
and resolution of violent conflict. In this light, the paper adopts a modified version of Assefa's (1993) definition of peace as involving three broad elements: the transformation of destructive conflictual interactions into cooperative and constructive relationships; reconciliation, leading to healthy, mature, ecological, social and personal relationships of interdependence; and justice. In this way, peace involves restructuring relationships (male notions of relationships) that promote war so that they can instead advance peace. Our modification of Assefa's conceptualisation of peace is particularly pertinent in terms of the relationship between gender relations and justice. Therefore, while agreeing with Assefa that peace involves the constructive transformation of violence, we add that it must be based on entrenching a politics of gender justice, mutual respect, tolerance and inclusivity which are all hallmarks of ubuntu. While these values are also found among men, we will argue that they are more likely to be exhibited by women. ${ }^{4}$ In this sense, a critical mass of women in politics can bring them to bear and make the difference between violent conflict and sustainable peace.

\section{Theoretical anchor: The human factor and peacebuilding}

\section{The human factor paradigm}

The human factor (HF) paradigm is an emerging theory of development which focuses on people-development. Its main exponent is Senyo Adjibolosoo who defines HF as the spectrum of personality characteristics and other dimensions of human performance that enable social, economic and political institutions to function and remain functional over time (Adjibolosoo 1995:33). According to him, such human characteristics and dimensions sustain the workings and application of the rule of law, political harmony, a disciplined labour force, just legal systems, respect for human dignity (rights) and the sanctity of life (Adjibolosoo 1995:33). The personality traits that enhance human performance in all spheres include integrity, responsibility, trustworthiness, commitment, selflessness, truthfulness, loyalty and discipline. Others are love, tolerance, sharing, wisdom, imagination,

4 We note that not all women have or exhibit these values, just as not all men have them. However, the social construction of gender and differentiated gender roles has generally socialised women to assume these values while men are generally socialised to assume the opposite. 


\section{Christopher Isike and Ufo Okeke Uzodike}

creativity and collegiality. Similarly, the HF theory holds that there are six broad dimensions of human performance and these include spiritual capital (knowledge of and connection to the laws of the universe); moral capital (sense of right or wrong); aesthetic capital (sense of beauty and ugliness); human capital (knowledge and skills); human abilities (competences) and human potential (dormant talents or untapped part of Being). These personality traits and dimensions of human performance are sine qua non for the attainment of the development aspirations of any society (Adjibolosoo 1995, 1999; Owusu-Ampomah 2003). Neglecting them in any development paradigm, planning or implementation process is a recipe for failure. As Owusu-Ampomah (2003: 66) puts it, without the HF, the quest for sustainable human development is a wild goose chase, as the human factor represents a paradigm shift that places premium on human values and positive qualities, not capital, institutions or policies.

According to Adjibolosoo (1999:62), human factor decay is the primary cause of the social, economic, political and educational problems of all societies - not lack of capital, inadequate political and economic institutional arrangements, or bad policies. In other words, negative human factor traits and dimensions are a source of underdevelopment, socio-political disorder and conflict, while positive human factor traits and dimensions are a necessary and sufficient condition for good governance, sustained economic growth, human-centred development and peace.

Apart from putting emphasis on human beings as the agency and end of development, the bottom line of the HF theory is that the quality of people who should power or enable the development process also matters. Therefore, the process of good governance must begin with human quality development 5 that will create an environment that is conducive to good governance, which in the context of this study will go a long way in preventing conflict $a b$ initio. The summary of Adjibolosoo's thesis therefore is that the absence of truth-telling, integrity, responsibility, accountability, trust, commitment, and transparency

5 In a public lecture, hosted by the School of Politics, University of KwaZulu-Natal, Pietermaritzburg, on the human factor and good governance, the guest speaker, Prof Senyo Adjibolosoo, said, 'personal growth in positive human factor qualities such as integrity, accountability, responsibility, commitment, selflessness and truthfulness creates a fertile environment for good governance' (10 July 2009). 
creates a fertile environment for serious social, economic, and political problems to thrive (Adjibolosoo 1995, 1999). This underscores the significance of good governance and political leadership in preventing and managing armed conflicts. ${ }^{6}$

\section{The human factor, women and peacebuilding in an African context}

As afore-mentioned, the significance of the HF paradigm is that beyond the human security and human rights (people-centred) approaches to development, the quality/type of people who can make peace and development possible also matters. In other words, there is need to focus on the character traits and human dimensions of people who are more likely to make peace and development happen, and appropriate their services accordingly. For example, while according to Adjibolosoo (1995), positive HF qualities such as integrity, accountability, selflessness and truthfulness can create a fertile environment for good governance and development, Lederach (2005) sees relatedness, collaboration, love, empathy and tolerance as necessary and sufficient factors for creating a fertile environment for peacebuilding. According to him, the capacity to imagine and generate constructive responses and initiatives associated with the daily challenges of violence can serve to transcend and ultimately break the grips of those destructive patterns and cycles within which conflict is perpetuated (Lederach 2005:29). Therefore, just as armed conflict takes place within a political context, there is also a political dimension of peacemaking which requires a kind of politics that is crucial for conflict transformation. This is the politics of responsibility, accountability, tolerance, empathy, accommodation, love, truth-telling and forgiveness all hallmarks of Lederach's moral imagination model of peacebuilding and the HF paradigm.

Certainly, in an African context, both the HF and Lederach's model of peacebuilding resonate well with the African worldview defined by ubuntu and

6 In reference to our conceptual framework, conflict arises when those in political positions fail to allocate scarce resources in a manner that wins the goodwill, trust, confidence and loyalty of citizens. Oftentimes, the resultant breakdown in relations between citizens and the state, and within citizens in the competition for access to increasingly scarce resources, manifest in violent conflict. 
which itself is based on positive relationships between people. Ubuntu captures the human essence of the African personality (male or female) which is validated by and built around its belonging to a collective or organic whole. As we have argued elsewhere, the meaning and practice of $u b u n t u$ in Southern Africa can be inferred from a Zulu maxim: umuntu ngumuntu ngabantu which literarily translates to 'a person is a person only because of other people' (Isike and Okeke-Uzodike 2010:689). The common and inter-related humanity ubuntu encapsulates is further underscored by Desmond Tutu when he argues that 'a person with ubuntu is open and available to others, affirming of others and does not feel threatened that others are able and good' (Tutu 1999:27). This is because 'he or she has a proper self assurance that comes with knowing that he or she belongs in a greater whole and is diminished when others are humiliated or diminished, when others are tortured or oppressed' (Tutu 1999:27). In the same vein, Knott (2010:623) contends that if the humanity of one is not respected, if a person's desires and experiences, their sentience of being are not recognised and acknowledged, then ubuntu (humanity) is undermined and compromised'. In pre-colonial Africa, the dominant worldview of ubuntu valued and maintained relationships because it was instrumental to realising the human essence and its survival. It was not one that ill-treated, neglected or humiliated women, since an injury to one was perceived as an injury to all. Rather it made people care for one another. Men did not need to feel threatened by women nor women by men as they both complemented each other in ways that allowed them to function cohesively as a social unit (Isike and Okeke-Uzodike 2010:690). In sum, HF traits and Lederach's prerequisites for peace which both overlap are reminiscent of $u b u n t u$ as we cannot have a peaceful and developed Africa if HF decay persists and we remain morally unaccountable to each other.

Within this context, the question is who, between men and women, are more likely to approach politics with positive HF traits and dimensions? Women generally are richly endeared with the moral capacity to care and to embrace curiosity and complexity as they are wont to rise above the historic traps of dualistic divisions which drive the cycles of violence, and in this way, transcend orthodox gender stereotypes and the oppressive relations they spew. This is possible because women are more relational than men and as such view the same phenomenon 
differently. For instance, women have the capacity to imagine themselves in a web of relationship even with their enemies (see Lederach 2005:34). Are women in Africa sufficiently disposed to the HF characteristics and dimensions which make peace and development possible? In essence, are African women more ubuntuconscious than men? Have African women ever had and do they still have the capacity to perceive things beyond what initially meets the ordinary eye - at a deeper level, leading to a critical turning point that will make the difference between violent protracted conflict and sustainable peace?

\section{Women and peacebuilding in pre-colonial African societies}

Women in different pre-colonial African societies had traditional peacemaking and peacebuilding roles as they were involved in mediating and preventing conflict within and between societies. Women's peace agency in these societies, and also their cultural and socio-political roles and contributions to the overall well-being of these societies, were rooted in ubuntu. These roles were reinforced by perceptions which stereotyped women as natural peacemakers, as being more pacific than men, and often symbolised as paragons of morality, sacredness, goodness and tenderness. Thus in most pre-colonial societies, virtues of patience, tolerance, humility and subtle persuasiveness were seen as essentially female attributes which were reinforced through socialisation patterns that promote women primarily as child-bearers, good wives, caregivers, arbitrators of conflict and peace promoters in the family and community (UNESCO 2003:8). For example, according to Ntahobari and Ndayiziga (2003), in traditional Burundian society, women were considered to be bridge-builders and symbols of unity between different families, clans, communities and ethnic groups through the institution of marriage. Accordingly, girls were socialised from an early age to be open-minded, adaptable and tolerant (Ntahobari and Ndayiziga 2003:20). This was the case in other societies such as in Nigeria, Cameroon, Namibia, Somalia and Tanzania (Awe 1977; Ngongo-Mbede 2003; Becker 2003; Mohammed 2003; Lihamba 2003). In these societies, women were expected to embody such virtues as compassion, patience, discretion, gentleness, modesty and self-control, which though they were considered inherent in womanhood, required reinforcement through upbringing, so that women could fulfil their role as peacemakers 


\section{Christopher Isike and Ufo Okeke Uzodike}

(Ntahobari and Ndayiziga 2003:20). For instance, Mohammed (2003:103) records that in periods of conflict amongst the Somalis, there were times when a group of young, unmarried women (known as Heerin) from one of the warring clans paid visits to the opposing clan without the knowledge or consent of their families. According to him, on arrival, the Heerin told the people that they were unmarried women, and that they wanted to be married and 'because this was a well known tradition, the young women were welcomed, and preparations were made to ensure that they were married. This immediately stabilised the situation and set in motion a peace process that eventually resolved the conflict' (Mohammed 2003:103). This kind of peace approach was only possible and successful because of the moral authority women were granted. They also often used these qualities and authority to mediate in disagreements between men by advising their husbands to toe the line of peace knowing that the consequences of violent conflict would especially be borne by them (the women). Such is the potency of this moral authority that women in post-colonial Africa have utilised them to wage peace in the DRC, Sierra Leone, Liberia, Guinea, Burundi and South Africa. Barring being essentialist, women have continually drawn on the moral authority granted to them by virtue of their being mothers, as creators of life, to call for peace throughout Africa (Mazurana and McKay 1999:20).

Traditionally, women in pre-colonial African societies were peace agents. According to Nwoye (no date), women engaged in peacebuilding through positive childcare, responsible mothering and nurturing of children in ways that prepared and socialised them towards peaceful co-existence. In most pre-colonial societies, a culture of peace, tolerance and an anti-war tradition are embedded in and transmitted through folktales, proverbs, poetry, songs and dance. Traditionally, women are often seen as the transmitters of these cultural values to their progeny and to future generations through such artistic expressions. For example, Mohammed (2003) used Somali stories, poetry, songs and proverbs to depict the important role of women as transmitters of knowledge and builders of a stable social fabric for society from the pre-colonial through the post-colonial era:

Mother! Without you

It would have been impossible to utter the alphabet

Mother! Without you 


\section{Reinventing women's roles as traditional peacebuilders in neo-colonial Africa}

It would have been impossible to learn how to speak

A child deprived of your care

Sweet lullaby

And soft touches

Would not grow up.

Mother! You are the source of love

The epitome of kindness (Mohammed 2003:102).

A very apt Somali proverb says: 'The values with which children are brought up precede their actual birth', and Mohammed (2003) contends that they are transmitted by mothers even while the child is still in the womb. In this regard, Somalians believe that, 'before becoming adults, we attend a basic school, and that school is mother' (Mohammed 2003:102). Indeed, in different pre-colonial societies, women used songs, proverbs, and poetry to transmit positive social capital values upon which peace is predicated. These values include patience, tolerance, honesty, respect for elders, communality and mutuality, compassion, regard for due discretion, gentleness, modesty, self-control, moderation, flexibility, and open-mindedness (Nwoye no date).

Women in pre-colonial societies also engaged actively in conflict mediation. As mentioned before, age was an important social base of political power in these societies and respect was given to the elderly in general, and to elderly women in particular. For instance, Nwoye (no date) reveals from the findings of her study on women and the peace process in six pre-colonial African states that 'the elderly woman' 'was respected by all, and played a key role in crisis management and conflict resolution'. This was the case amongst the Tuburs in Cameroon, for example, where the Wog Clu (old women) were solely responsible for conflict mediation and were consulted on problems which disturbed communal peace (Ngongo-Mbede 2003:32). Thus, as Nwoye (no date) argues, 'when a conflict degenerated into armed violence, an appeal would usually be made to a third party of mature years to calm the tension and reconcile the combatants. Such an appeal for mediation was usually made to a woman who enjoyed the consideration and respect of all who knew her'. In the same vein, because of the sanctity attached to womanhood, women, mostly elderly women, were used as peace envoys to 


\section{Christopher Isike and Ufo Okeke Uzodike}

facilitate peace negotiations (Mohammed 2003; Lihamba 2003). This was only possible because during war women were the only ones who could move across the zones of conflict freely and without much danger and as such were used by warring parties to study the situation, assess the prospects for peace, and facilitate contact and communication between the two warring parties.

Women in most pre-colonial African societies also served as intermediaries in conflicts between human beings and nature. For example, according to NgongoMbede (2003), in the land of Mungo of the Cameroon, any misfortune occurring in the community brought the latter to seek the mediation of the Kalbia (married women). In these communities, in general, misfortune and calamities were taken to imply the existence of conflicts between the people. For instance:

... in the philosophy of these communities, such a succession of misfortune was not fortuitous. It was the sign that love and peace were absent from the community, and prompted the women to decide to organize a Mbabi. The latter was organized in a grove or on a crossroads, after consultation of the oracles. It was exclusively a meeting of women who had reached the age of the menopause. The ceremony was presided over by a woman of very advanced years whose moral integrity was usually universally acknowledged. Men could on occasion, be associated with the Mbabi. Even in such exceptional cases, however, it was the women who organized and presided over the ceremony of reconciling human beings with themselves, with relatives and with nature (Ngongo-Mbede 2003:31).

The study documents that amongst the Beti, Mangissa and the Eton in Cameroon, the $M b a b i$ was a common purification rite aimed at restoring peace, and women frequently engaged in it both for peace, community building and development. This is also consistent with the purification rituals (uutoni), which women in Northern Namibia performed on soldiers returning from war. The idea was to cleanse them of the guilt and consequences of spilling blood during war, which if not done would have adverse effects for social harmony, peace and stability in their societies (see Becker 2003).

Concisely, as Nwoye (no date) concludes, African women's roles as mothers, wives, and aunts were put to effective use in peacebuilding and conflict resolution 
in pre-colonial African societies. Women participated firmly in inculcating the culture of peace in the children and in the practice of conflict mediation among warring factions within the family and the community. They also commanded important positions in conflict resolution rituals and were significant peace activists through their roles as peace envoys in times of conflict. As we will show in the next section, though corrupted by the colonial interruption of Africa's sociocultural existence, ${ }^{7}$ these values which are influenced by $u b u n t u$ are still alive and can be used for promoting peace among warring families, communities and nations in neo-colonial Africa. They can be developed into an African feminist ethic of peace which can be the cornerstone of effective conflict prevention, mediation and peacebuilding.

\section{Women waging peace in neo-colonial African states}

The African feminist ethic of motherhood and care which drove women's political participation and peace agency in pre-colonial African societies is still very much alive amongst contemporary African women. This is daily being expressed by ordinary women across the continent in the face of their marginalisation and oppression at the private and public levels of society, specifically also in conflict situations. For example, in the heat of the bitter Tutsi and Hutu civil war in Burundi, Hutu women of Busoro near the Burundi capital of Bujumbura, joined their Tutsi counterparts in the neighbouring Musanga village to march peacefully to the local government secretariat where they both demanded an end to the killing. According to Fleshman (2003), one day the women of Musanga got fed up with the chilling consequences of the war and collected what food and clothing they could for victims in Busoro and subsequently rallied their Busoro counterparts to march for peace, clasping their hands to sing 'Give us peace. Give us peace now!' for hours before making their separate dangerous ways back home (Fleshman 2003:1-2). Although, as Fleshman (2003:2) recorded, 'the war continued, something important had changed. The road that divided them

7 For example, according to Amadiume (1997:104), 'Islamic patriarchy in Africa was followed by European imperialism and finally the present subjugation of African societies and people under European-imposed nation-states. It has introduced a new gender politics, favouring men and undermining the traditional system of balance of power politics between African men and women'. 


\section{Christopher Isike and Ufo Okeke Uzodike}

now connected them, and through their local peace group, Twishakira amahoro (we want to have peace), the women of the villages have worked to keep the connection strong.

Another example of neo-colonial African women acting locally and often spontaneously across battle lines in pursuit of peace is the case of Congolese women who overcame partisan, ethnic and other sectional differences to organise for peace in the Democratic Republic of the Congo (DRC). Ahead of the UN-initiated formal peace talks (Inter-Congolese Dialogue) in Sun City (South Africa) which included only 40 (12\%) women amongst 340 delegates, women from across the DRC, including representatives from the warring parties, government and civil society, gathered in Nairobi to forge a common position of peace. At the end of the Nairobi debate, the women discovered that, 'however deep their differences, they shared an overriding desire for peace, a broad commitment to the Lusaka peace accord and significantly, a common determination to remove constitutional and legislative obstacles to women's equality after the war' (Fleshman 2003:15). This much was contained in a joint declaration and programme of action that offered a gender perspective to the dialogue issued by the women (Rehn and Johnson Sirleaf 2002). Specifically, the declaration and programme of action called for 'an immediate ceasefire, the inclusion of women and their concerns in all aspects of the peace process, and adoption of a 30\% quota for women at all levels of government in any final settlement' (Fleshman 2003:15).

Challenged by the lack of a critical mass of women in the actual peace negotiations in Sun City, the women selected 33 of themselves to join the official 40 women representatives to the peace talks as advisers. Excluded therefore from the formal peace talks, the 33 women advisers functioned effectively as facilitators of the peace process as they prepared technical documents and position papers for the official delegates, lobbied the men for peace and generally served as conduit between the masses yearning for peace back home and the peace delegates in Sun City. Of note here is that the women adopted traditional African women's instruments of drama, poetry and appeal to motherly sacredness including, sometimes, civil disobedience to make their presence felt, and tilt the negotiators towards peace. For example, reminiscent of pre-colonial women's power to withdraw conjugal rights from men if they refused to listen to women's appeal for peace during conflict with 


\section{Reinventing women's roles as traditional peacebuilders in neo-colonial Africa}

neighbouring communities, ${ }^{8}$ the Congolese women's caucus subtly threatened to denounce the men back home, telling them that if they went back home without peace the people would beat them' (Fleshman 2003:16). And when at the end of the peace talks, the parties could not reach an agreement, 'the women's caucus blocked the doorway and announced to reporters that delegates would have to remain in the meeting hall until peace was agreed'. However, in general, cognisant of the centrality of relationships in enabling sustainable peace and the significance of maintaining their relations with men, which was a main concern of precolonial African matriarchy, the women caucus chose to avoid confrontation with the men, knowing that if it was to impact on the process from its outside position, it was necessary to establish and maintain good relations with the men. This was important because men traditionally resented actions that appeared to challenge 'traditional' gender roles and more so that the Congolese men, in the first place, reluctantly agreed to the modest increase in female delegates (Fleshman 2003:16). The account of one of the women caucus members, Ms Bibiane, in this regard is poignant enough to be reproduced:

At first the men were hostile because there was this group of women entering 'their' space. But we approached them in a way that made them feel secure. In African culture, the woman is your mother. The woman is your wife and your sister. If your mother or sister is talking to you, you have to listen ... We didn't demonize the men or try to take their place (Fleshman 2003:16).

Clearly, this resonates well with the moral imagination as the women displayed a capacity to transcend every-day conventions of human relations based on ethnic, partisan or gender sentiments by generating constructive responses and initiatives that, while rooted in the day-to-day challenges of the DRC conflict, would ultimately break the grips of those destructive patterns and cycles within which the conflict is perpetuated and dragged (see Lederach 2005). In this way,

8 See Amadiume $(1987,1997)$ and Nzeogwu (2000) for more details on how pre-colonial Nigerian women used their conjugal powers to serve as checks on the excesses of maledominated politics. They contend variously that women in different communities used the threat of their nakedness to leverage policy advantages for themselves and for society in general since oftentimes their needs were communal in focus. 


\section{Christopher Isike and Ufo Okeke Uzodike}

the women laid a foundation for eventual peace as they planted the seed of a 'yes we can' mentality amongst a people whose over 50 years experience of conflict has probably blotted their capacity to imagine that peace is possible.

From Senegal, the conflict-ridden Mano River basin countries of Liberia and Sierra Leone to Burundi, the DRC, South Africa and Mozambique, there are many more such examples across Africa today where women are using their traditional weapons to wage peace, or at least, ask questions of a masculinised and zero-sum politics characterised by corruption, competition, intolerance and conflict, which underlies and perpetuates a cycle of chronic under-development in the continent. The peace work of the Mano River Women's Peace Network (MARWOPNET), a transnational women's organisation consisting of women from Liberia, Sierra Leone and Guinea, is well known in this regard, especially in mediating the escalating conflict between Liberia and Guinea in 2001. This feat, according to Fleshman (2003:18), demonstrated the potential of women's peacemaking efforts in Africa. Defying nationality differences and rather focusing on the things that hold them together as women, mothers and daughters of Africa, MARWOPNET was able to get presidents Charles Taylor of Liberia, Ahmad Tejan Kabbah of Sierra Leone and Lansana Conte of Guinea to meet, a feat that previously proved fruitless for the then Organisation of African Unity (OAU) and the sub-regional Economic Community of West African States (ECOWAS) with the full complement of their diplomatic arsenal. Although the women drew the respect of President Taylor for being 'courageous' enough to meet with him to convince him to attend a regional peace summit with president Conte, it was the women's meeting that was seen as more audacious. According to Fleshman (2003), realising that their strategy of focusing on human insecurity implications of conflict which worked with President Taylor was not working with President Conte who remained adamant that he would not meet with Taylor, the women changed tactics. The women, through one of their representatives, told President Conte point-blank:

You and President Taylor have to meet as men and iron out your differences, and we the women want to be present. We will lock you in this room until you come to your senses, and I will sit on the key (Fleshman 2003:18). 
Fleshman records that when her comments were translated into French for the president, there was a long silence, and then he started laughing after which he commented: 'What man do you think would say that to me? Only a woman could do such a thing and get by with it'. Crediting the women for changing his mind to attend the peace summit, the president said:

Many people have tried to convince me to meet with President Taylor, but only your commitment and your appeal have convinced (Fleshman 2003:18).

The point of rendering these reports is to underscore the fact that the feminist ethic of care, based on motherhood and women's sacredness that was appropriated by pre-colonial African women to wage peace and maintain societal harmony, is still very much a part of the core of contemporary African women and is constantly being deployed in conflict situations such as in the Niger Delta of Nigeria and KwaZulu-Natal in South Africa (Isike 2009). They can be reinvented and developed into a model of African feminist peacebuilding which women in conflict-torn African states or regions can utilise as an ideological rallying point to transform politics and conflict, and ipso facto create an environment conducive to sustaining development.

\section{Converging the past and present: The plausibility of an African feminist ethic of peacebuilding}

According to Ifi Amadiume (1997:100), there are two unique contributions that African women have made to world history and civilization: matriarchy and the dual-sex character of African political systems, which is directly related to the matriarchal factor. She contends that African matriarchy was a fundamental social and ideological base on which African kinship and wider social and moral systems, such as ubuntu or ujamaa, rest (Amadiume 1997). In her view, authentic African matriarchy had 'a very clear message about social and economic justice as it was couched in a very powerful goddess-based religion, a strong ideology of motherhood, and a general moral principle of love' (Amadiume 1997:101). This was opposed to imperialist patriarchy which has a basic masculinist ideology that celebrates violence, valour, conquest and power in varying degrees, and 


\section{Christopher Isike and Ufo Okeke Uzodike}

which, according to Diop (1989), denied women their rights, subjugating and properticising them in a strict hierarchical system of family where the man (husband or father) was supreme and had power of life and death over the woman. On the other hand, pre-colonial African matriarchy and patriarchy co-existed in what Diop (1989) refers to as a 'harmonious dualism' between men and women, and what Amadiume (1997:93) describes as 'fluid demarcation'. According to her, this 'embodied two oppositional or contesting systems, the balance tilting and changing all the time' (Amadiume 1997:93-94). In this regard, she concluded that genders in pre-colonial African societies were fluid as they were a means of dividing, but also a means of integrating and co-opting in dynamic ways that enabled stability and order based on justice, equity and fairness. This enabled a system where women's power became based on the centrality of their economic role in relation to men, and men's general belief in the sacredness of women as mothers. This was given expression in widespread goddess worship across different communities including those that were patriarchal. According to Amadiume (1997:102),

In indigenous African religion, mystical powers and worldly prosperity are gifts inherited from our mothers. The moral ideals of this system encouraged the matriarchal family, peace and justice, goodness and optimism and social collectivism, where the shedding of human blood was abhorrent.

Even in pre-colonial patriarchal cultures like those of the Zulus, women were traditionally able to stop fights by falling over the person being beaten. According to a study by Rakoczy (2006:202), one of her respondents indicated that Zulu women's ability to stop fighting in this way may be due to respect for women as 'the persons who bring children', the life-givers. She contends rightly that this tradition is also commonplace amongst the Sotho people, narrating how a woman's brother was rescued by another woman who heard his cry as he was being beaten by several men. The rescuing woman 'stepped into the fray, put a blanket over her brother and probably saved his life' (Rakoczy 2006:202). The rescuing woman did not have to know who the man being beaten was to intervene for the violence to stop. She knew instinctively as a mother who cared for her children that she had to act, more so in the understanding that she is connected to him as a human being 


\section{Reinventing women's roles as traditional peacebuilders in neo-colonial Africa}

living in the same community. The aggressors on their part knew that they could not continue beating their victim once the woman intervened in the way she did. Continuing would have meant violating the woman as well, and this they were not prepared to do as men because of the socio-cultural implications.

The crux of our argument here is that women's existence and power in precolonial African societies were based on an ethic of care that was rooted in their motherhood and their nature, which was tolerant of difference, collaborative, non-violent and, as such, peaceful. ${ }^{9}$ Their peace activism and agency was in itself rooted in a broader communal ideology (ubuntu, ujamaa, negritude, humanism or African socialism) which operated on the basis of the mutuality of human interests through a web of relationships where everyone played their part for the good of the collective and the validation of the personal. In these societies, women never saw or placed themselves in a dichotomous relationship with men, rather, gender relations were fluid, dynamic and complementary in difference as Amadiume (1997) espoused. Indeed as Gasa (2007) admonished, there is nothing wrong with Euro-American and Occidental feminist tradition just as there is nothing wrong with or limited about Arab, Asian or African feminisms. However, 'we must acknowledge the different historical and situational realities which may call for a different approach and an adjustment of a particular framework' (Gasa 2007:228). In her view, the connection between the detail, pattern and big picture of African feminism will assist African men and women in 'understanding our location, developing tools of analysis that are appropriate to our own situation, and applying them in a way that illustrates and illuminates rather than obscures our real and lived experiences and their multiple meanings' (Gasa 2007:228). As mentioned before, motherhood qualities of care and nurturing and women's positive dispositions towards collaboration, interconnectedness and peace do not imply weakness. Rather they portray strength, as they are consistent with the affective and relational foundation of people's existence with each other.

9 This is not to say that all women are necessarily pacifist, as there are also records of women who have taken decisions to go to war, and of women who have actively participated as combatants. Even pre-colonial African history shows records of women regents waging war. 
According to Nodding (in Van Soest 1995:166-167), these qualities are the foundation of a feminist perspective and ethic of peace rooted in receptivity, relatedness and responsiveness. She contended that such a relational approach to peacebuilding may be more typical of women than men, arguing further that an approach based on law and principle is the approach of the 'detached one' (men who are detached from the experience of nurturing children and community), and therefore suggested that a feminist view, which is concerned with people, is an alternative that men can embrace as well as women. Drawing from the utility of the relational ethic of care, Dorothy van Soest argues that 'a relational ethic concentrates on the moral health and vigour of relationships, not individuals, and recognises that moral judgements and decisions about how to act must take into account the relations in which moral agents live and find their identities' (Van Soest 1995:167).

\section{Supportive empirical evidence}

Findings from a study of women, conflict, politics and peacebuilding show that the defining features of such a feminist peace model include a caring and nurturing nature based on motherhood, empathy to community needs (which makes women less corrupt than men), tolerance of difference, sharing and collaboration, all of which are undergirded by the notion of relational mutuality, i.e., that men and women exist in a web of relationships where their existence are intrinsically connected (ubuntu). From the study, women respond to conflict by embracing peace and adopting collaborative methods of engagement. The attitude of women to conflict, which underscores their response and the peace-oriented roles they play in conflict resolution, is not unconnected to the African woman's feminist ethic of care which values interrelationships, connectedness and empowerment rather than conflict and competition. For example, according to Mrs Iyoha, ${ }^{10}$ while men view conflict as 'struggle or war which must be fought', women tend to see conflicts as 'necessary evils in communities' and only give in to or endorse war after all avenues for peaceful resolution of conflict have been exhausted, and even

10 Interview (13 June 2007) with Mrs F.E. Iyoha, the Clerk of the Legislative Arm and Chief Administrative Officer of Oredo Local Government Area of Edo state, Nigeria, and a former Head of Family Support Programme in the Local Government Area. 


\section{Reinventing women's roles as traditional peacebuilders in neo-colonial Africa}

then, they tend to hope for and pursue prospects for peace during war. Also, since the injured and dead in conflicts are more often their sons, husbands and brothers, they tend to focus on the cessation of violence and the rebuilding of their homes, families and communities. ${ }^{11}$ Indeed, according to Mrs Okolocha, ${ }^{12}$ 'because women feel the impact of conflict more than men, they naturally advocate for peace and pursue conflict resolution'. This is corroborated by a cumulative $73 \%$ (131 out of 180 responses) of the women in both case studies who were affected by conflict and who said they responded to the conflict in their area by 'creating alternatives for survival' (47), 'working towards peaceful resolution of the conflict' (12), 'accepting their fate and moving on' (62) or 'helping to rebuild community' (10). Another finding (lesson) from King's study in this regard is instructive:

In performing their tasks with male colleagues, women were perceived to be more compassionate, less threatening or insistent on status, less willing to opt for force or confrontation over conciliation, even it is said less egocentric, more willing to listen and learn - though not always - and to contribute to an environment of stability which fostered the peace process (King 1997:4).

Concisely, women have a positive attitude and approach towards peace. While men spoil for a fight, women toe the alternative route for peace and calm to reign. Apart from interviewee's responses, reasons the questionnaire respondents gave ranged from the population stake of women in the study areas, and women's interest in peace and community development, to the perception that women are less corrupt compared to men and are better suited to consensus building than men as shown in the multiple response table below.

11 Focus group discussion (3 May 2007) with 10 women in Odi, Bayelsa State, Niger Delta.

12 Interview (12 June 2007) with Mrs H.O. Okolocha, a politician, writer and lecturer of English and Literature at the University of Benin, Nigeria. 
Table 1: Reasons why women in politics will enhance peacebuilding

\begin{tabular}{|l|c|c|}
\hline \multirow{2}{*}{ Why women in politics will bring peace } & \multicolumn{2}{|c|}{ Responses } \\
\cline { 2 - 3 } & N & Percent \\
\hline $\begin{array}{l}\text { Women are more than half the population and } \\
\text { should be part of the solution to societal problems }\end{array}$ & 85 & 22,2 \\
\hline $\begin{array}{l}\text { Women are equally capable leaders and will help } \\
\text { the quality of decisions that will also address their } \\
\text { concerns }\end{array}$ & 102 & 26,7 \\
\hline $\begin{array}{l}\text { Women are equal stakeholders in ensuring peace } \\
\text { and development }\end{array}$ & 95 & 24,9 \\
\hline $\begin{array}{l}\text { Women are less corrupt and better suited to } \\
\text { consensus building }\end{array}$ & 100 & 26,2 \\
\hline Total & 382 & 100,0 \\
\hline
\end{tabular}

(Adapted from Isike 2009:249)

Our survey findings reveal that women's peace agency is also rooted in their agency for good governance. An aggregation of responses on the question of women's significant contributions to good governance and development in the study areas show that women are perceived as community developers (having installed electricity and running/tap water, and being concerned about poverty alleviation and community building/development). They are also seen as introducing a caring and sharing approach to politics that is rooted in their femininity and motherhood (showing softness to society, joy and motherly care, remembering everyone, and being not autocratic and corruption free) and as being generally peace-oriented (praying for community peace, bringing harmony and standing against trouble). The significance of their good governance agency for peacebuilding can be understood in the light of the way in which the male dominated leadership's failure to allocate resources 


\section{Reinventing women's roles as traditional peacebuilders in neo-colonial Africa}

equitably has fuelled social and armed conflict, not only in the study areas, but also in other parts of Africa.

\section{Concluding remarks}

Studies have shown that women have the required spectrum of personality characteristics and dimensions of human abilities/capacities that are necessary and sufficient for good governance and peacebuilding (see Van Soest 1995; King 1997; Ngongo-Mbede 2003; Ntahobari and Ndayiziga 2003; Anderlini 2007; Isike 2009). While Lederach (2005) may not have clearly articulated the political dimensions of peacebuilding, the peace process indeed requires a kind of politics which is crucial for its success. This is the politics of responsibility, accountability, tolerance, empathy, accommodation, love, truth-telling and forgiveness. And it is the politics that women generally represent and can bring to bear if they come into politics as women. These are the virtues that bring us to the pregnant moment: the turning point that makes the difference between violent conflict and peace. Applying this to the peace discourse enables us to call attention to the kind of human beings who can make peace and development possible rather than focusing on the kind of institutions, techniques and systems that guarantee peace (Lederach 2005). Within this human-centred framework, research into the realities and potentials of women, who constitute over half of the world's population, as instruments of a more peaceful world, is a worthwhile venture.

Women's peace agency is rooted in the values of their womanhood and an ethic of care that values relationships, inter-connectedness and empowerment from which springs forth empathy, co-operation, tolerance and love. These values are necessary requirements for amicably resolving conflict and for sustaining peace. They worked very well in pre-colonial African societies, especially in matriarchal ones, where women had traditional roles in preventing violence, mediating conflicts and reconciling those in conflict. In some of these traditional societies, gender was defined in flexible terms that allowed men and women to straddle socially constructed male and female spaces. For instance, according to Amadiume (1997), a flexible gender system in pre-colonial Igbo societies in Nigeria was enabled by a flexible language 


\section{Christopher Isike and Ufo Okeke Uzodike}

structure which presented 'no language or mental adjustment or confusion in references to a woman performing a typical male role' (Amadiume 1997:17). Appropriating the utility of a flexible gender system for peacebuilding in Africa, Amisi (2008:11) contends that the idea of a flexible gender system provides for a language that allows a formulation of a concept of peace and also of war in gendered terms that approximates the reality of a number of African societies whose gender relations are similar to those of the Ibos that Amadiume studied. ${ }^{13}$ In other words, although the idea of flexible gender and language systems may be alien to some African societies that have a different world-view of gender relations, it offers a valuable model of understanding armed conflict and peace, and 'it can be a resource for the envisioning of peace even in societies that may not be aware of the idea' (Amisi 2008:12). It is more so that in Africa, women are traditionally known to have the critical skills, spiritual and social capital as well as human potential and moral imagination capacity to transform conflict from violence to peace. Indeed, African women were and continue to be an embodiment of the ethic of care and the moral imagination which are very critical to changing the face and essence of politics to be more human-centred. This is expected to have some positive significance for conflict prevention, resolution and peacebuilding in the continent if properly appropriated.

\section{Sources}

Adjibolosoo, Senyo 1995. The human factor in developing Africa. Westport, CT, Praeger.

Adjibolosoo, Senyo 1999. Rethinking development theory and policy: A human factor critique. Westport, CT, Praeger.

Amadiume, Ifi 1987. Male daughters, female husbands: Gender and sex in an African society. London, Zed Books.

Amadiume, Ifi 1997. Re-inventing Africa: Matriarchy, religion and culture. London, Zed Books.

Amisi, B.K. 2008. Indigenous ideas of the social and conceptualising peace in Africa. Africa Peace and Conflict Journal, 1 (1), pp. 1-18.

13 See Weir (2007) and Gasa (2007) who also document evidence of women in pre-colonial Southern African societies (i.e. Zulus, Lovendus) assuming what today are strictly defined as 'male roles' by engaging in woman to woman marriages, owning cattle (traditional symbol of male power) and fighting wars. 


\section{Reinventing women's roles as traditional peacebuilders in neo-colonial Africa}

Anderlini, Sanam Naraghi 2007. Women building peace: What they do, why it matters. London and Boulder, Lynne Rienner.

Assefa, Hizkias 1993. Peace and reconciliation as a paradigm: A philosophy of peace and its implications on conflict, governance and economic growth in Africa. Nairobi Peace Initiative (NPI) Monograph Series. Nairobi, NPI.

Awe, Bolanle 1977. The Iyalode in the Traditional Yoruba Political System. In: Schlegel, A. Sexual stratification: A cross-cultural view. New York, Columbia University Press.

Becker, Heike 2003. Women, politics and peace in Northern Namibia. In: UNESCO (United Nations Educational, Scientific and Cultural Organisation) Women and peace in Africa: Case studies on traditional conflict resolution practices. Paris, UNESCO.

Brine, Jacky 1999. Under-educating women: Globalising inequality. Buckingham, Open University Press.

Centre for Advanced Social Science (CASS) 2005. Enhancing the capacity of women leaders of community organizations towards peace-building in the Niger-Delta region, Nigeria. Port Harcourt, CASS.

Diop, Cheik A. 1989. The cultural unity of Black Africa: Domains of matriarchy and patriarchy in classical antiquity. London, Karnak House.

Fleshman, Michael 2003. African women struggle for a seat at the peace table. Africa Recovery, 16 (4), pp. 15-19.

Gasa, Nomboniso 2007. Feminisms, motherisms, patriarchies and women's voices in the 1950s. In: Gasa ed. 2007.

Gasa, Nomboniso ed. 2007. Women in South African history. Cape Town, Human Sciences Research Council Press.

Isike, Christopher A. 2009. Feminising the peace process: A comparative analysis of women and conflict in the Niger-Delta (Nigeria) and KwaZulu-Natal (South Africa). Ph.D. thesis, University of KwaZulu-Natal.

Isike, Christopher and Ufo Okeke-Uzodike 2008. Modernizing without westernizing: Redefining African patriarchies in the quest to curb HIV and AIDS in Africa. Journal of Constructive Theology, 14 (1), pp. 3-20.

Isike, Christopher and Ufo Okeke-Uzodike 2010. Moral imagination, Ubuntu and African women: Towards feminizing politics and peace-building in KwaZulu-Natal (South Africa). Gandhi Marg, 31 (4), pp. 679-709.

King, A.E. 1997. Success in South Africa - impact of women in the peace process in South Africa - includes related article on women in peace missions. UN Chronicle. Available from: <http://findarticles.com/p/articles/mi_m1309/is_n3_v34/ai_20267837/> [Accessed 4 Sep 2009].

Knott, Jessie L. 2010. Umntu ngumntu ngobuntu wabantu. Gandhi Marg, 31 (4), pp. 611-627. 


\section{Christopher Isike and Ufo Okeke Uzodike}

Lederach, John Paul 2005. The moral imagination: The art and soul of building peace. Oxford, Oxford University Press.

Lihamba, Amandina 2003. Women's peace-building and conflict resolution skills, Morogoro Region, Tanzania. In: UNESCO 2003.

Mazurana, Dyan E. and Susan R. McKay 1999. Women and peace-building. Montreal, International Centre for Human Rights and Democratic Development.

Mohammed, Abdi 2003. The role of Somali women in the search for peace. In: UNESCO 2003.

Ngongo-Mbede, Valerie 2003. The traditional mediation of conflicts by women in Cameroon. In: UNESCO 2003.

Ntahobari, Josephine and Basilissa Ndayiziga 2003. The role of Burundian women in the peaceful settlement of conflicts. In: UNESCO 2003.

Nwoye, Miriam A.C. no date. Role of women in peace building and conflict resolution in African traditional societies: A selective review. Available from: <http://www. afrikaworld.net/afrel/chinwenwoye.htm> [Accessed 12 Feb 2009].

Nzeogwu, Ngozi 2000. African women and the fire dance. Available from: <http://www. westafricareview.com/vol2.1/nzegwu2> [Accessed 14 Aug 2007].

Owusu-Ampomah, Kwame 2003. Human development paradigm and agenda: A wild goose chase. In: Adjibolosoo, Senyo ed. The International Development Program of Activities: What are we doing wrong? Bloomington, Author House.

Patel, Nandini 2001. Conflict resolution through regional organizations in Africa. In: Maloka, E ed. A United States of Africa? Pretoria, AISA (Africa Institute of South Africa).

Rakoczy, S. 2005. Religion and violence: The suffering of women. Sexuality in Africa Magazine, 2 (4). Available from: <http://www.arsrc.org/downloads/sia/dec05/dec05. pdf> [Accessed 18 Sep 2008].

Rehn, Elisabeth and Ellen Johnson Sirleaf 2002. Women, war, peace: The independent experts' assessment on the impact of armed conflict on women and women's role in peace-building. Progress of the world's women, Vol. 1. UNIFEM (United Nations Development Fund for Women).

Tutu, Desmond 1999. No future without forgiveness. London, Pinter.

UNESCO (United Nations Educational, Scientific and Cultural Organisation) 2003. Women and peace in Africa: Case studies on traditional conflict resolution practices. Paris, UNESCO.

Van Soest, Dorothy 1995. A feminist ethic for peace. In: Van den Bergh, Nan ed. Feminist practice in the 21st century. Washington, D.C., National Association of Social Workers.

Weir, Jennifer 2007. Chiefly women and women's leadership in pre-colonial Southern Africa. In: Gasa ed. 2007. 